\title{
NUMA1/RARA Fusion Protein
}

National Cancer Institute

\section{Source}

National Cancer Institute. NUMA1/RARA Fusion Protein. NCI Thesaurus. Code C99360.

A fusion protein (2284 aa, $260 \mathrm{kDa}$ ) encoded by the NUMA1/RARA fusion gene. This protein is comprised of the first $1883 \mathrm{~N}$-terminal amino acids of the nuclear mitotic apparatus protein 1 , including the globular domain and the alpha helical dimerization domain, fused to the amino acids 61 to 462 of the retinoic acid receptor alpha protein, including the ligand-binding, dimerization and DNA-binding domains. 